\title{
Distribution of Attractions and Tourism Accomodation in Simanindo, Samosir District, Indonesia
}

\author{
Fitra Delita ${ }^{1}$, Tumiar Sidauruk ${ }^{2}$, Sugiharto $^{3}$ \\ \{delitafitra@gmail.com, tumiargeo@yahoo.com, sugih.unimed@gmail.com\} \\ Universitas Negeri Medan, Medan Indonesia
}

\begin{abstract}
Tourism has become an extremely important sector in national economic development. Samosir District is one of the famous tourist destinations in Indonesia. There are 75 tourist sites spread over 9 subdistricts in Samosir. The distribution of attractions is located mostly in the subdistrict of Simanindo. The objectives of this research are to analyze the distribution of attractions and describe tourism accommodation in Simanindo Subdistrict. The qualitative approach is used in this research. The data used are compiled from observation and documentary. The results reveal that almost 19 tourist attractions spread in Simanindo Subdistrict. The attractions can be classified as natural attractions, historical attractions, and cultural attractions. There are 58 hotels (1326 rooms) and other accommodation to support 19 tourist sites in this area. The hotels consist of 2-star hotels totaling 5 buildings; 1-star hotel, class I jasmine hotels amounted to 30 buildings; class II jasmine hotel amounted to 17 buildings; and class III jasmine hotel amounted to 5 buildings.
\end{abstract}

Keywords: distribution, attractions, accommodation, tourism

\section{Introduction}

The tourism sector is a business area that has high prospects at this time. Globally, an estimated 74 million people derive direct employment from the tourism business: from travel and transportation, accommodation, promotion, entertainment, visitor attractions and tourist retailing [1]. In Indonesia, the tourism sector is one of the biggest foreign exchange-earners. In 2015 foreign tourist visits contributed Rp. 144 trillion of foreign exchange earnings. The Ministry of Tourism predicts that by 2020, the tourism sector will become the number one contributor to foreign exchange in Indonesia. Especially now that there is a "Wonderful Indonesia" branding that can contribute to tourism achievement. North Sumatra Province is one of the 10 main tourist destinations in Indonesia. There are 339 attractions spread across all regions in 33 regencies/cities in North Sumatra Province.

Samosir Regency has 75 attractions spread across 9 districts. Of these, as many as 39 tourist sites $(52 \%)$ are natural attractions, 14 historical attractions (18.67\%), 9 cultural attractions (12\%), 12 historical and cultural attractions (16\%), and 1 spiritual attraction $(0.013 \%)$ [3]. However, the development of this potential is still constrained partly because of the lack of community friendliness, site location, and artifacts owned/managed by a clan and the lack of resources in tourism management. Other threats include inadequate accessibility, low stakeholder cooperation and low awareness of Sapta Pesona [4]. Simanindo District is a district that has the most tourist distribution and is diverse compared to 8 other districts in Samosir Regency. In this district, there are natural attractions, historical attractions, cultural 
attractions, and historical \& cultural attractions. However, not all of these attractions are known and visited by tourists. Places that serve as the main tourist destination for local and international tourists are Tuk Tuk Siadong Tourism Village.

Meanwhile, new attractions and alternative tourist accommodations in Simanindo District are not yet widely known or visited by tourists. The spatial distribution of these attractions will provide modeling of the location of attractions through mapping as well as a description of the characteristics of these objects. So the purpose of this study is to analyze the distribution of tourist attractions and tourist accommodation in Simanindo District, Samosir Regency, North Sumatra Province. This study will be useful for consideration of tourism promotion and other policies related to tourism development in Simanindo District. Spatial knowledge and distributions of tourist sites should assist policy makers and service providers in market segmentation, planning, and product expansion to local and international tourists [4].

\section{Method}

This study uses a qualitative approach to data collection through observation and documentation. Measurement of the coordinates of tourist attractions is done using a GPS device. This coordinate data is useful for determining the location of tourist attractions on a map. Besides, to coordinate point data, this study also uses the Simanindo District Administration Map which is processed through Arc GIS 10.5 software to produce a Map of the Tourist Attraction Distribution in Simanindo District. Data were analyzed descriptively in multiple stages consisting of reduction, categorization, displaying of data and drawing conclusions.

\section{Finding and discussion}

\subsection{Spatial Distribution of Tourist Attractions in Simanindo Subdistrict}

Simanindo District has the most tourist attraction compared to 8 other districts in Samosir Regency. There are 19 attractions which include natural attractions, cultural attractions, and historical attractions.

Table 1. Distribution of Attraction in Simanindo Subdistrict

\begin{tabular}{rlrrlc}
\hline No & Name of Attractions & Type of Attraction & No & Name of Attractions & $\begin{array}{c}\text { Type of } \\
\text { Attraction }\end{array}$ \\
\hline 1 & $\begin{array}{l}\text { Makam Raja } \\
\text { Sidabutar }\end{array}$ & Historical and Cultural & 11 & $\begin{array}{l}\text { Desa Wisata Tuk- } \\
\text { tuk Siadong }\end{array}$ & Natural \\
2 & Sipokki & Historical and Cultural & 12 & $\begin{array}{l}\text { Siulak Hosa bukit } \\
\text { Beta }\end{array}$ & Natural \\
3 & Museum Huta Bolon & Historical and Cultural & 13 & Tuk-tuk Siasu & Natural \\
4 & Museum Tomok & Historical and Cultural & 14 & Pulo Malau & Natural \\
5 & Museum Gok Asi & Historical and Cultural & 15 & Agrowisata Aek & Natural \\
& & & & Naktonang & Natural \\
6 & Batu Marhosa & Historical and Cultural & 16 & Gua Lontung & Natural \\
7 & Situs Pagar Batu & Historical and Cultural & 17 & Gua Alam Sangkal & Natural \\
8 & Sigale-Gale & Cultural & 18 & Sibolazi Beach & Natural \\
9 & Batu Parsidangan & Historical & 19 & Batu Hoda Beach & \\
10 & Batu Kursi & Historical & & & \\
& Parhapuran & & & & \\
\hline
\end{tabular}

Table 1 presents that there are 9 natural attractions, 7 cultural and historical attractions, 2 historical attractions and 1 cultural attraction in Simanindo Subdistrict. Each tourist attraction 
has its charm, but the attraction that most attracts visitors is natural tourist attractions such as tourist villages and beaches. This is very reasonable because one of the main objectives of tourism activities is an escapade from all the daily routines and work. Therefore, enjoying nature is the right choice. The primary motive for pleasure tourism is a real or perceived need to escape temporarily from the routine situations of the home, the workplace and the familiarity of their physical and social environments, the many theories of tourist motivation may differ quite substantially in their interpretation and explanations of resulting tourist patterns and behaviors [1]. Tourism leisure (holiday) especially the urban population especially those in major economic centers- because of stress accumulated in the deployment of dynamic economic processes today [5]. Distribution of attraction in Simanindo Subdistrict can be observed in Figure 1.

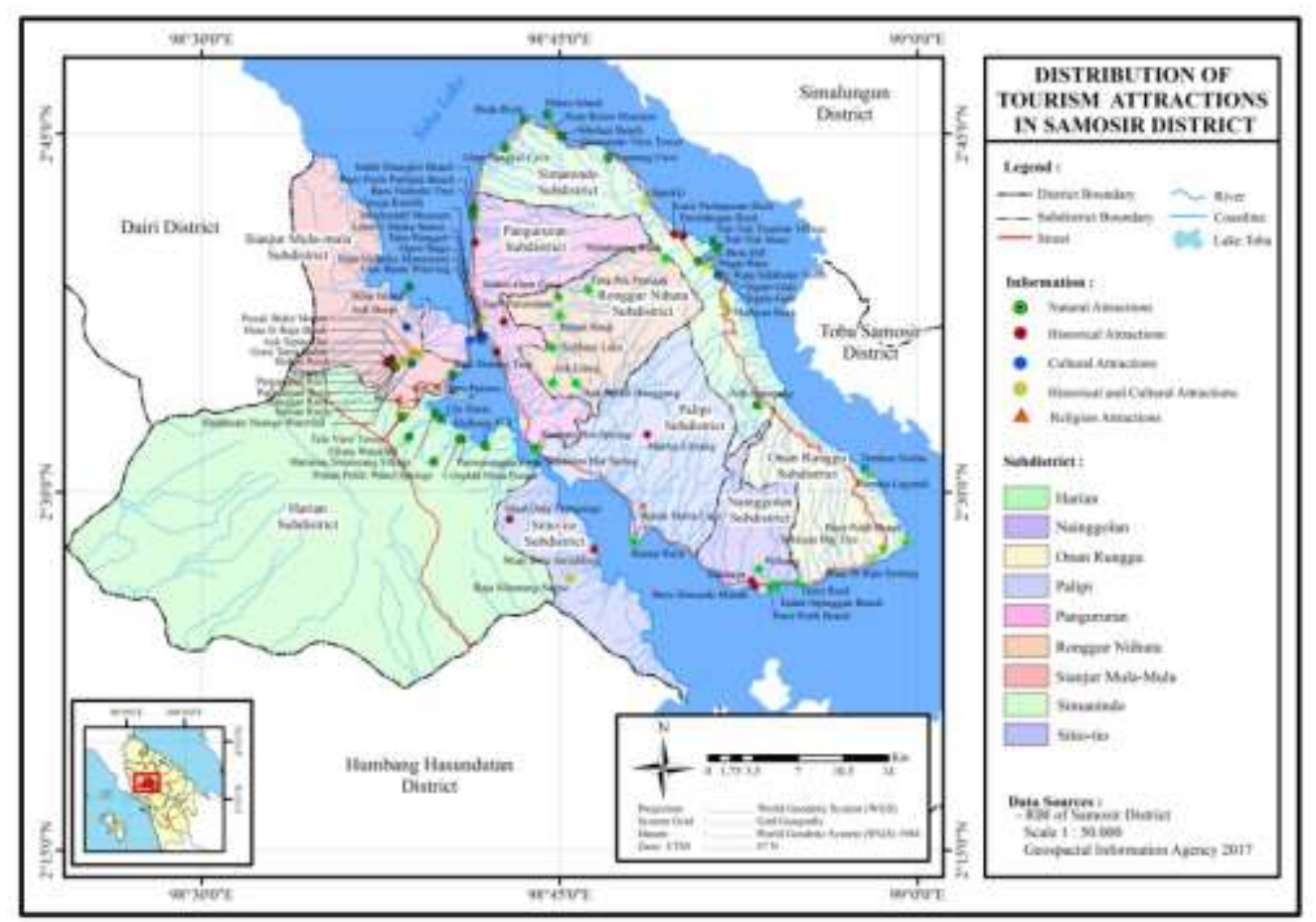

Fig. 1. Distribution of tourism attractions in Samosir district

Figure 1 shows the distribution of tourist attractions in Simanindo Subdistrict is more widespread in the east and around the outskirts of Lake Toba. This indicates the location of the area which borders directly with Lake Toba is a strategic area and has the potential for tourism development, both because of the beautiful panorama and historical and cultural sites. This is similar to the development of an area that is strongly supported by its location and accessibility. Other tourism objects that are frequently visited and developed in Simanindo District are those located on the edge of the lake, which can be reached by crossing vessels, and which are located close to the highway. Meanwhile, tourist objects that are located far inland with sufficiently difficult access will be devoid of visitors. Some regions experience obstacles in tourism development due to the issue of land ownership by indigenous people as well as local people who are antipathic to tourists. Tourist attraction would be of little value of 
its locations were inaccessible by transportation. Physical isolation and inadequate transport facilities are, clearly, handicaps to tourism. Furthermore, Community involvement in tourism activities is also very important. The role of society can't be ignored, especially in interacting with tourists.

The availability of accommodation facilities is also one of the factors that influence the development of attractions in addition to the attractions offered, location and accessibility. Among the 9 sub-districts in Samosir Regency, Simanindo District has the most accommodations, namely hotels with various qualities such as 2-star, 1-star and jasmine class. Related to tourism facilities in Simanindo sub-district, there are 58 hotels and other accommodations (1326 rooms and 2440 beds) that support 19 attractions in this area, including 11 -star hotel building ( 51 rooms and 165 beds), 52 -star hotel buildings ( 354 rooms and 627 beds), 30 class I jasmine hotel buildings (715 rooms), 17 class II jasmine hotel buildings ( 574 rooms) and 5 class III jasmine hotel buildings ( 359 rooms). Lodging prices vary depending on the class and facilities provided. Most of the lodgings are located in the Tuk-Tuk Siadong Tourism Village, resulting in a high concentration of tourists at this attraction.

\section{Conclusion}

Various tourist attractions in Simanindo Subdistrict which are spread along the edge of Lake Toba are dominated by natural attractions. Accommodation facilities in the form of hotels and other types of lodging are also concentrated in one area, namely Tuktuk Siadong Tourism village, so tourists also tend to visit this location more than 18 other attractions in Simanindo District. Tourist attraction to a particular location is influenced by the attraction offered, the facilities available such as accommodation, accessibility and other services that can be managed by the government and the community. Development of facilities and infrastructure, in general, is still constrained by ownership of land status by indigenous peoples and the community's assumption that tourists can hurt their lives, even though community involvement is also a determining factor for the success of tourism development programs. As such, a collaboration between stakeholders including the government, private sector, and the community is necessary.

Acknowledgment. Thanks to all who have been involved in this research, especially to the Rector and Research Institute of Medan State University who have funded this research with a research contract No: 027/ UN33.8/LL/2019.

\section{References}

[1] Williams, Stephen. : Tourism Geography A New Synthesis. Abingdon: Routledge (2009)

[2] Tourism Ministry of Republic Indonesia. Kementerian Pariwisata. Laporan Akuntabilitas Kinerja Kementrian Pariwisata. (2015)

[3] Fitra, Delita., Sugiharto., Sidauruk, Tumiar., Yenni, Novida and Damanik, M. Ridha Syafii.: GIS Application In Mapping Of Tourism Attractions In Samosir District North Sumatra Province. IOP Conf. Series: Journal of Physics DOI:10.1088/17426596/1175/1/012226, (2019) 
[4] Sugiharto, Delita, Fitra., Sidauruk, Tumiar.: The Spatial Distribution of Tourist Sites in Samosir, North Sumatera. Sumatra Journal of Disaster, Geography and Geography Education, Vol 3, No. 1, (pp. 1-9), June, (2019) http://sjdgge.ppj.unp.ac.id

[5] Tureac, C.E., Anca, Turtureanu.: Types and Forms of Tourism. Acta Universitatis Danubius (2008) 